\title{
Extremely Long-Closed Galls of a Social Aphid
}

\author{
Utako Kurosu $^{1}$ and Shigeyuki Aoki ${ }^{2}$ \\ ${ }^{1}$ Faculty of Economics, Chuo University, 742-1 Higashinakano, Hachioji, Tokyo 192-0393, Japan \\ ${ }^{2}$ Faculty of Economics, Rissho University, Osaki 4-2-16, Tokyo 141-8602, Japan
}

Correspondence should be addressed to Utako Kurosu, ukurosu@tamacc.chuo-u.ac.jp

Received 10 December 2008; Accepted 18 June 2009

Recommended by James Traniello

The aphid Nipponaphis monzeni (Hormaphidinae, Nipponaphidini) forms large, hard, completely closed galls on the evergreen Distylium racemosum, its primary host, in south-western Japan. By marking 100 galls on a tree and monitoring them over five years, and by sampling many immature galls from another tree in various seasons and dissecting them, we found that galls of $N$. monzeni are initiated in June, that they remain small for at least 21-22 months and that tiny fundatrices survive for over one year. Some galls rapidly expand during April/May in the third year. Others remain small and swell up in the fourth year and still others in the fifth year. Full-grown galls open in November/December, and alates fly to evergreen oaks, the secondary host. Thus galls of N. monzeni take 2.5 years to mature at earliest (3-year life cycle) and some galls 3.5 or 4.5 years (4- or 5-year life cycle).

Copyright ( $) 2009$ U. Kurosu and S. Aoki. This is an open access article distributed under the Creative Commons Attribution License, which permits unrestricted use, distribution, and reproduction in any medium, provided the original work is properly cited.

\section{Introduction}

In general, aphid galls formed on a tree wither and die within the year [1], but a few exceptions have been reported from the subfamily Hormaphidinae. It takes longer than one year for galls of Tuberaphis styraci (Cerataphidini) to mature on the temperate deciduous Styrax obassia [2]. Galls of Ceratoglyphina styracicola (Cerataphidini) grow slowly and last for up to 20 months on the subtropical evergreen Styrax suberifolius [3]. Nipponaphis distyliicola (Nipponaphidini), on the evergreen Distylium racemosum, forms completely closed galls that remain small over several months and rapidly expand in the following spring [4]. Although not yet confirmed, galls of some other cerataphidines may also last for over one year [5-7]. These galls are (or are supposed to be) biennial and do not last beyond two years. We found extremely long-lasting galls in the Nipponaphidini, which remain closed for at least two and a half years.

Species of the tribe Nipponaphidini induce galls on Distylium trees (Hamamelidaceae) in eastern Asia [8-10]. The tribe includes several social species that produce defensive nymphs in the galls [11-15]. About a dozen nipponaphidines are known to form galls on Distylium racemosum in Japan $[16,17]$. Among them, Nipponaphis monzeni forms the largest and hardest galls on the tree $[18,19]$. The mature brown galls (Figure 1(d)) are up to $8.5 \mathrm{~cm}$ in height [19] and the gall wall becomes lignified and so hard that one cannot crack them with bare hands. Even adult Japanese monkeys (Macaca fuscata yakui) are not always successful in opening the galls with their teeth [20]. Because of the conspicuous size and hardness, galls of $N$. monzeni are well known among people living in south-western regions of Japan where trees of $D$. racemosum are commonly planted. The old empty gall is called "Saru Bué (monkey whistle)" [21] and children blow into it through the exit hole to whistle $[21,22]$. This species is also peculiar in that its first-instar nymphs repair their gall in a self-sacrificing manner, by discharging a large amount of body fluid $[23,24]$. It has been unknown, however, when and how galls of N. monzeni are initiated and developed to mature. Through our preliminary (unpublished) study with a few galls, we have noticed that galls of $N$. monzeni last beyond two years. Later, by marking many galls, we confirmed that it takes more than two years for the galls to mature and open, and that there are three groups of galls that mature in different years; galls of one group grow to mature in the third year, galls of another group in the fourth year, and galls of the last group in the fifth year. This peculiar process of gall growth is herein reported. 


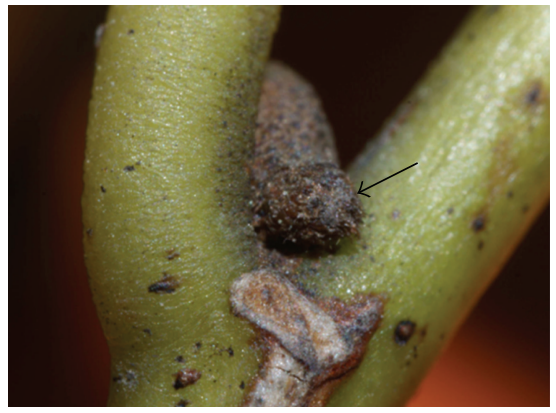

(a)

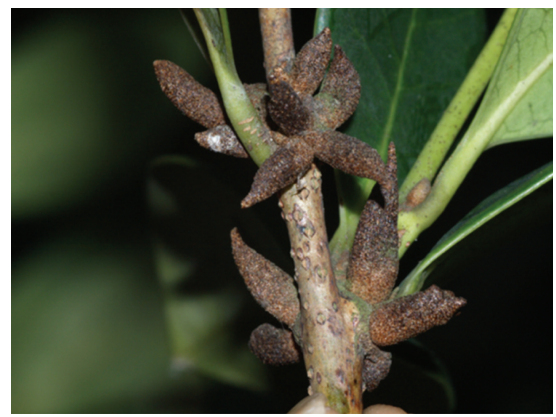

(c)

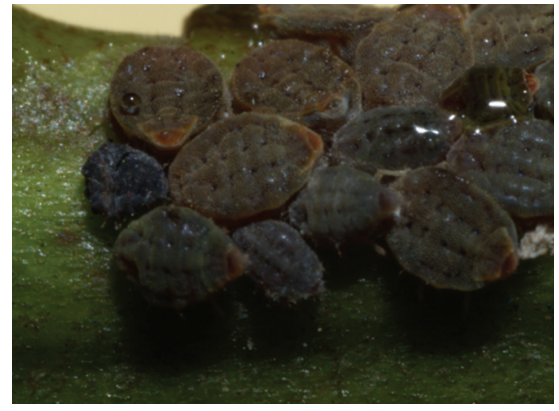

(e)

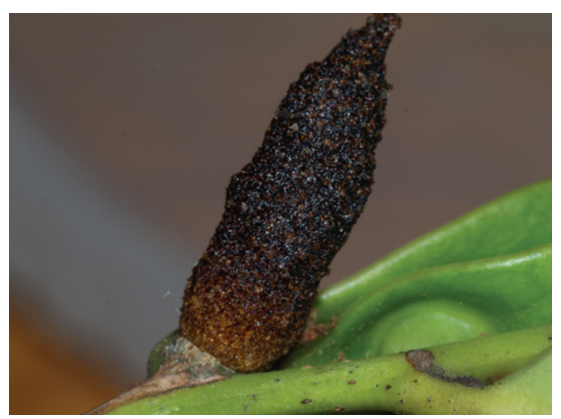

(b)

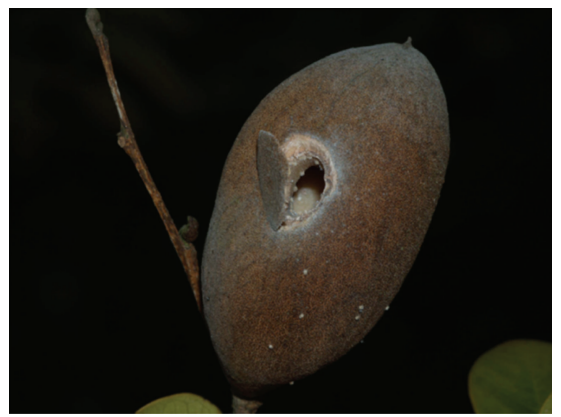

(d)

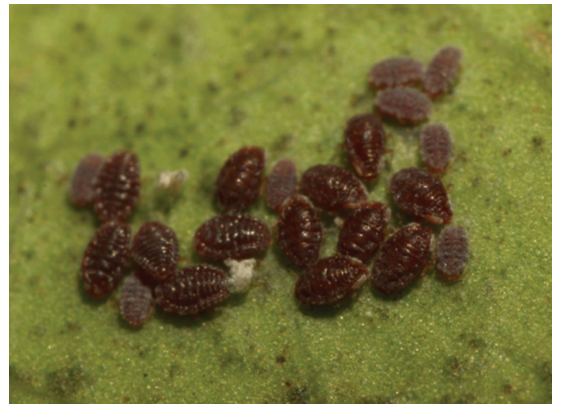

(f)

FIgURe 1: Nipponaphis monzeni: (a) an overwintered tiny gall (on 12 March 2008) that was formed on the base of an axillary bud of Distylium racemosum in the previous year; (b) after the first winter such a gall has grown to a cone-shaped gall (on 19 May 2008); (c) several coneshaped galls with the hardened wall (on 29 October 2007); (d) a full-grown gall with a round exit hole (on 8 December 2008); (e) secondaryhost generation (apterae and nymphs) on a twig of Lithocarpus edulis (on 9 January 2008); (e) sexuals on the underside of a leaf of $D$. racemosum (on 30 April 2008).

\section{Hitherto Reported Life Cycle of Nipponaphis monzeni}

The aphid Nipponaphis monzeni migrates obligatorily between Distylium racemosum, its primary host, and evergreen oaks such as Quercus glauca, Q. myrsinaefolia, and Castanopsis sieboldii, its secondary hosts, and induces galls on D. racemosum in south-western regions of Japan $[18,19,23]$. The mature galls are ellipsoid or fig shaped, about 35$86 \mathrm{~mm}$ and $26-66 \mathrm{~mm}$ in the major and minor diameters, respectively [19]. The gall wall becomes lignified, very hard, and up to $3.4-3.7 \mathrm{~mm}$ thick $[18,19]$. In the end, late in autumn, a round opening appears (just as a submarine hatch opens; see Figure $1(\mathrm{~d})$ ) and one gall may produce $600-880$ alates [19]. The alates (emigrants) migrate to leaves of oaks and give birth to first-instar nymphs on the underside. These first-instar nymphs settle on twigs and become scale-like apterous adults [18] (Figure 1(e)). Nymphs produced by the apterous adults all develop into alate sexuparae in the following spring. No aphids remain on the secondary host during summer $[8,18]$. The alate sexuparae fly back to leaves of Distylium and produce males and sexual females there [18] (Figure 1(f)). They copulate and the females deposit eggs onto the bases of buds [25]. First-instar fundatrices, which induce galls, hatch from these eggs in May [8]. Because galls of $N$. monzeni rapidly become large and hence noticeable during May, it has been supposed that eggs hatch soon and that the fundatrices quickly develop their galls to the full size, almost within a month $[18,26]$. However, small galls of N. monzeni were found already in March and even earlier, before the return migration of alates from oaks. This fact suggests that galls of $N$. monzeni might remain small over 
a long period, as is shown for N. distyliicola [4]. The prime purpose of the present paper is to make it clear whether this is the case.

\section{Materials and Methods}

3.1. Study Tree and Inducing Galls. A tree (Tree N) of Distylium racemosum, which had been planted in our garden, Niiza $\left(35.79^{\circ} \mathrm{N}\right)$, Saitama Prefecture, Japan, was used as a "host" tree. We introduced a total of 2026 alate sexuparae of Nipponaphis monzeni onto the tree between 12 and 29 April 2001. Distylium racemosum is not naturally distributed in Saitama Prefecture. Around the garden, there were no natural colonies of $N$. monzeni on oaks, nor were trees of D. racemosum during the experimental period (from 2000 to 2006). These sexuparae were collected from a colony on a tree of Quercus glauca in Atsugi, Kanagawa Prefecture, and from another colony on a tree of Q. myrsinaefolia in Niiza, both of which had been established by the introduction of many alates (emigrants) from 18 galls of N. monzeni to the oak trees. The 18 galls were collected from trees of $D$. racemosum in Shinkiba (about $29 \mathrm{~km}$ south-east of Niiza) along Tokyo Bay on 6 December 2000. The alate sexuparae were placed on the upper sides of leaves one by one with a pair of forceps. To prevent them from taking off, we wetted a target leaf with water before placing alates on it. These alates were stuck on the leaf but, after the water evaporated, most of them walked onto the underside and larviposited there.

3.2. Rearing of Sexuals. A cut-off twig of Distylium racemosum was placed in a plastic container, and 53 alates that had been collected from the two colonies on the oaks were introduced into the container between 23 and 26 April 2001. When eggs were found, they were kept in glass vials under room temperature to determine approximately when eggs hatched.

3.3. Monitoring Galls. New shoots began to grow on Tree N in late March or early April during the experimental years. We made a map of some branches of Tree $\mathrm{N}$ and recorded the position of incipient galls on the map. Between 24 September and 12 October 2001, 55 galls were mapped. At that time, because all galls were very tiny (about $1 \mathrm{~mm}$ or less in width), soft, and fragile, we did not measure the exact size. Between 28 April and 6 May 2002, additional 43 galls were found and mapped. On 24 November 2002 and on 3 June 2003, two more galls, which had been overlooked before, were marked. We recorded whether these 100 marked galls were alive (and opened finally) and measured the width and height with vernier calipers to the nearest $0.1 \mathrm{~mm}$ up to nine times: (1) between 28 April and 6 May 2002, (2) on 23 and 24 November 2002, (3) on 9 and 15 March 2003, (4) on 3 June 2003, (5) on 3 December 2003, (6) on 30 May 2004, (7) on 5 December 2004, (8) on 22 May 2005, and (9) on 14 December 2005. The sizes of measured galls are shown in the text as mean $\pm \mathrm{SD}$, together with range and the sample size $(n)$ in parentheses. Because we carelessly overlooked a gall twice, this sample size does not exactly accord with the number of live galls.
3.4. Sampling of Immature Galls. To know how a colony of Nipponaphis monzeni develops within the gall, young galls were sampled from trees in Shinkiba in various months. Because zero- to 15-month-old galls could certainly be distinguished from older galls, these age-knowable galls were selectively sampled from a tree (Tree S1), which harbored many old and live galls of N. monzeni, from October 2007 to September 2008: on 29 October, 9 January, 12 March, 4 April, 16 April, 30 April, 19 May, 2 June, 16 June, 7 July, 5 August, and 17 September. From nine to 29 age-knowable galls were collected on each day. A few additional galls were sampled from other trees there. We also sampled many older (ageuncertain) galls from Tree S1 on 31 March 2007 and 2 June 2008. They were deposited in $80 \%$ ethanol and later were measured and dissected to examine the colony structure. Since galls of $N$. monzeni were completely closed, dead aphids remained in the galls. The number of live and dead aphids were counted. The age of the sampled galls is estimated based on the assumption that they were formed in June and is indicated in months. In 2008, new shoots began to grow on Tree S1 between 16 and 30 April. On several other trees in Shinkiba buds had already burst by 16 April.

3.5. Identification of Galls. Because cone-shaped galls (Figures 1(b), 1(c)) of Nipponaphis monzeni are peculiar in structure and appearance, it was easy to distinguish them from immature galls of other nipponaphidines on Distylium racemosum at the time of sampling. Tiny semispherical galls (Figure 1(a)) of $N$. monzeni much resemble those of $N$. distyliicola and Monzenia globuli, both of which are formed on (mainly axillary) buds and were seen on trees in Shinkiba. Galls of M. globuli are initiated about one month earlier (in May), and offspring of the fundatrix appear already in July [27], while galls of $N$. monzeni are initiated in June and the fundatrix does not produce offspring until the next spring (see Results). Hence there is little possibility of misidentification between the two species. On the other hand, galls of $N$. distyliicola are initiated about one month later (in July) and the fundatrix produces offspring from October onward [4]. There would therefore be some possibility of misidentification for semispherical galls sampled in August and September. However, galls of N. distyliicola were much fewer than those of N. monzeni in Shinkiba during 20062008, particularly on Tree S1, from which we sampled most galls of N. monzeni; hence, misidentification, if any, would hardly affect our results.

3.6. Examination of Morphology of Aphids. Many aphids in young galls were macerated in $10 \% \mathrm{KOH}$ solution, stained with acid fuchsin or Evans blue, and mounted in balsam (for method, see, e.g., [28]), and their morphology was examined under a light microscope.

\section{Results}

4.1. Reared Sexuals and Eggs. The alate sexuparae placed on leaves (and those introduced into the plastic container) soon 


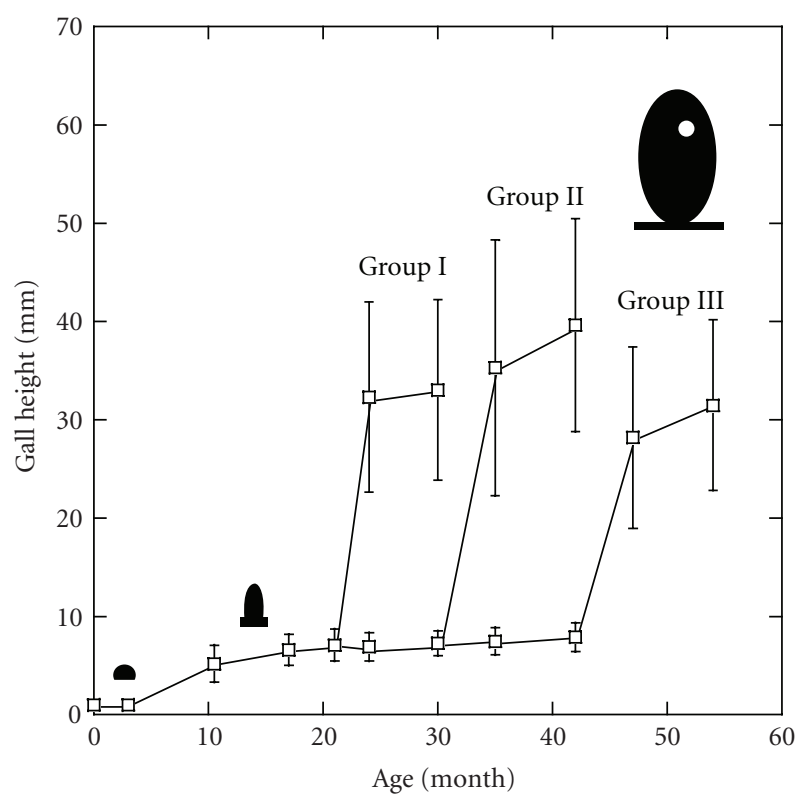

FIGURE 2: Development of galls of Nipponaphis monzeni formed on a tree (Tree N). Gall height is indicated as mean (square) $\pm \mathrm{SD}$ (vertical bar). Groups I, II, and III correspond to the first, second, and third expanding groups, respectively, in the paper.

gave birth to sexuals that were reddish brown in color on the underside. On 11 May 2001 we noticed eggs laid in the container for the first time, on the bases of leaf blades, sides of midribs, and near the margin of curled leaves. On 14 May 54 eggs found in the container were transferred into glass vials. Between 23 and 30 May 2001 six eggs hatched into firstinstar fundatrices, but the others died without hatching. This accords with Takahashi's [8] remark that, in Osaka, eggs of Nipponaphis monzeni hatch in May.

4.2. Development of Monitored Galls. The development of the monitored galls on Tree $\mathrm{N}$ for up to 54 months (4.5 years) is summarized in Figure 2.

4.2.1. Fundatrices and Incipient Galls. On 13 June 2001 many first-instar fundatrices were found walking on twigs of Tree N. Incipient galls were already formed on axillary buds of leaves. Many of them were not yet closed up. We found many closed small galls in September 2001. They were semispherical, about $1 \mathrm{~mm}$ or less in diameter, tinged with brown and covered with white hairs.

4.2.2. Galls after 10 or 11 Months. Between 28 April and 6 May 2002, approximately 10 or 11 months after the gall formation, $32(58.2 \%)$ of the 55 incipient galls marked the last year were found alive. The live 32 galls and 43 newly marked galls were slender in shape, $2.5 \pm 0.7 \mathrm{~mm}$ (range 1.0-4.6) in width and $5.2 \pm 1.9 \mathrm{~mm}$ (range 1.2-9.7) in height $(n=74)$.
4.2.3. Galls after 17 Months. On 23 and 24 November 2002, approximately 17 months after the gall formation, 74 of the 75 marked galls were found alive. An additional gall, which had been overlooked, was newly marked. All these galls became slightly larger but still were cone shaped. They were $3.2 \pm 0.6 \mathrm{~mm}$ (range $2.1-5.0$ ) in width and $6.6 \pm 1.6 \mathrm{~mm}$ (range 3.5-10.8) in height $(n=75)$.

4.2.4. Galls after 21 Months. On 9 and 15 March 2003, 71 of the 75 galls were found alive. These galls were still small, and $3.2 \pm 0.6 \mathrm{~mm}$ (range 2.0-5.0) in width and $7.1 \pm 1.6 \mathrm{~mm}$ (range 3.6-11.2) in height $(n=71)$. Hereafter, these galls developed to mature, but in three different years, that is, in the third (2003), fourth (2004), or fifth (2005) year.

4.2.5. Galls after 24 Months. On 3 June 2003, 68 of the 71 galls were alive. Of the 68 galls, 40 (59\%) had begun rapidly growing and became swollen and were $28.1 \pm 6.6 \mathrm{~mm}$ (range 16.9-41.4) in width and $32.3 \pm 9.6 \mathrm{~mm}$ (range 19.0-61.3) in height $(n=40)$. Those galls that grew to mature in the third year are referred to as galls of the first expanding group. On the other hand, the remaining 28 (41\%) were still small. One hitherto overlooked cone-shaped gall, which did not expand in this year, was newly marked. Those that did not swell up were $3.5 \pm 0.8 \mathrm{~mm}$ (range 2.4-5.4) in width and 6.9 $\pm 1.4 \mathrm{~mm}$ (range 3.4-8.9) in height $(n=29)$.

4.2.6. Galls after 30 Months. On 3 December 2003, all (29) galls that had not expanded in this year remained closed and alive and were $3.5 \pm 0.7 \mathrm{~mm}$ (range 2.4-5.0) in width and $7.3 \pm 1.3 \mathrm{~mm}$ (range 4.0-9.2) in height $(n=29)$. Of the 40 galls of the first expanding group, two failed and 32 were open. Of the remaining six, five successfully opened by 31 December 2003, but one did not open and failed. The 40 galls, including the failed three, were $28.3 \pm 6.4 \mathrm{~mm}$ (range 17.2-40.9) in width and $33.0 \pm 9.1 \mathrm{~mm}$ (range 19.8-60.9) in height $(n=40)$.

4.2.7. Galls after 35 Months. On 30 May 2004, of the 29 galls that had not swelled up in the third year, nine (31\%) were expanding, of which one was broken, perhaps by a bird. These galls, referred to as of the second expanding group, were $36.3 \pm 9.3 \mathrm{~mm}$ (range 21.9-51.0) in width and $35.3 \pm$ $13.0 \mathrm{~mm}$ (range 20.0-56.8) in height $(n=9)$. The other 20 $(69 \%)$ remained small and were $3.9 \pm 0.8 \mathrm{~mm}$ (range 3.0 5.6) in width and $7.5 \pm 1.4 \mathrm{~mm}$ (range 5.0-10.1) in height $(n=20)$.

4.2.8. Galls after 42 Months. On 5 December 2004, of the nine galls of the second expanding group, the broken one was found dead, and the remaining eight were open and were $40.5 \pm 9.0 \mathrm{~mm}$ (range 22.7-52.7) in width and $39.6 \pm$ $10.8 \mathrm{~mm}$ (range 29.9-57.0) in height $(n=8)$. The 20 galls that had not swollen in the fourth year, still remained small and were $4.2 \pm 0.8 \mathrm{~mm}$ (range 3.2-5.6) in width and $7.9 \pm$ $1.5 \mathrm{~mm}$ (range 5.5-11.1) in height $(n=20)$. 
4.2.9. Galls after 47 Months. On 22 May 2005, all 20 galls were expanding. These galls (referred to as of the third expanding group) were $34.0 \pm 10.9 \mathrm{~mm}$ (range 12.8-47.7) in width and $28.2 \pm 9.2 \mathrm{~mm}$ (range 14.0-46.5) in height $(n=19)$. Thus, of the 69 galls that were alive on 3 June 2003, $40(58 \%), 9(13 \%)$, and $20(29 \%)$ turned out to be of the first, second, and third expanding groups, respectively.

4.2.10. Galls after 54 Months. On 14 December 2005, of the 20 galls of the third (last) expanding group, one was found dead and 15 were open and the remaining four were still closed. The live 19 galls were $38.6 \pm 7.6 \mathrm{~mm}$ (range 18.150.0 ) in width and $31.5 \pm 8.6 \mathrm{~mm}$ (range 17.3-46.4) in height $(n=19)$. The fate of the four galls had been followed until 8 October 2006. One of the four withered and fell off the tree, and the three contained many dead aphids including alates when cracked on 8 October. Once-swollen galls that had not opened by January did not open thereafter.

Of the 15 successfully opened galls, four were marked between 24 September and 12 October 2001, which no doubt indicates that some galls last for over four years.

4.2.11. Galls Formed on a Single Bud. More than one gall was at times formed on a single bud. Of 65 buds on which our mapped galls were formed, 20 harbored more than one gall (up to five). On eleven of the 20 buds, more than one gall (up to four) successfully developed and later expanded to mature. On seven of the eleven buds, all galls (up to three) expanded in the same year (on five buds in 2003, on one in 2004, and on the remaining one in 2005), while on the other four buds at least one gall expanded in a different year.

Also on other trees in the field (in Shinkiba), both cone-shaped and expanded galls were at times found at the position of a single bud.

4.3. Sampled Galls and Colony Development. Colony development for the first 15 months is summarized in Figure 3.

4.3.1. Incipient Galls. In Shinkiba many sexuparae and sexuals of Nipponaphis monzeni were found on the undersides of leaves of Distylium racemosum on 30 April 2008 (Figure 1(f)). Many tiny newly-formed galls of N. monzeni, some of which had not yet closed up, were found on buds of Tree S1 on 16 June 2008. These galls each contained a first-instar fundatrix. Some fundatrices were just attacking buds. Galls were formed on axillary buds of newly developed shoots or on auxiliary buds of terminal buds, or rarely on terminal buds themselves.

Such tiny yet completely closed galls (Figure 1(a)) were found from July to March/April. These galls each contained a single fundatrix. The fundatrices were still first instar in August, and eight out of 21 fundatrices were 2 nd instar on 17 September. They were probably adults from late October onward. Tiny galls collected on 8 April still contained a single fundatrix only, but one gall already contained a first-instar nymph of the second generation.

4.3.2. From 10- to 15-Month-Old Galls. Tiny galls on buds began to develop from April/May in Shinkiba (Figure 1(b)).

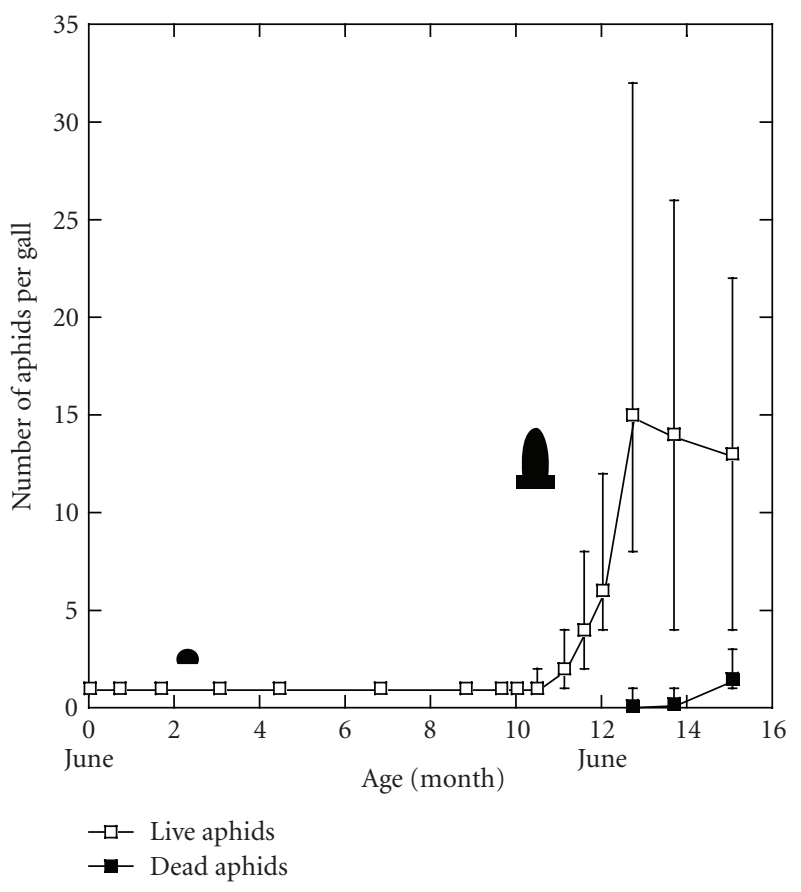

FIGURE 3: Colony development in galls of Nipponaphis monzeni for the first 15 months. Vertical lines indicate the range for the number of aphids per gall. The sample sizes are 20, 17, 20, 21, 13, 20, 15, 17, $23,25,17,29,20,13,9$, and 20 from the left to right. The ages are calculated based on the assumption that all galls were initiated on 15 June.

Most of them were still $1 \mathrm{~mm}$ or less in height on Tree S1 during April, and up to $1.7 \mathrm{~mm}$ on 19 May. (We found one gall which was $7.9 \mathrm{~mm}$ in height on another tree in Shinkiba on 30 April 2008.) These galls contained a live fundatrix and 0-3 nymphs of the second generation. The galls grew further, reaching 5.5-11.2 $\mathrm{mm}$ in height on 7 July. In many cases, the axillary bud on which a gall had been formed sprouted; then, the gall was located at the base of a new shoot. In others, the axillary bud did not sprout; the bud might later be atrophied. During this period, colony size also increased, reaching 833 on 7 July (Figure 3 ). In most galls, the fundatrix was still alive after one year. Dead fundatrices were found in one out of 13 (13-month-old) galls on 7 July and two out of nine (14-month-old) galls on 5 August. Thus, fundatrices of $N$. monzeni, despite their small size, live for over one year (Figure 3 ). There were usually two (sometimes one or three) apterous adults with thickened hind legs in addition to several nymphs. By September the gall wall became thick and hard, and galls ceased growing. From 20 (15-monthold) galls collected on 17 September, no live fundatrix was found. Eight of the 20 galls contained one dead thick-legged aptera or two besides the dead fundatrix (one of the galls also contained one dead nymph).

4.3.3. Galls Collected at the Beginning of June. One hundred cone-shaped galls collected on 2 June 2008 were dissected. They were $2.5 \pm 0.7 \mathrm{~mm}$ (range $0.6-5.1$ ) in width and $5.8 \pm$ $1.8 \mathrm{~mm}$ (range 1.0-10.1) in height. These galls would include 
those that passed one, two, and three wintering seasons, or 12-, 24-, and 36-month-old galls. (Besides them finally expanding galls were seen on the tree. They would be 24,36 , or 48 months old.) There was in fact only a weak correlation between gall surface area (calculated by assuming that the gall is a right circular cone) and the number of live aphids ( $r=0.65)$ or the total number of live and dead aphids $(r=0.62)$. (With gall volume instead of surface area, the correlation coefficients decreased to 0.59 and 0.56 , resp.; cf. [29].) The number of live aphids in the galls is shown as a histogram, together with information on the number of dead aphids, in Figure 4(a). It was easy to discriminate 12month-old galls from 24- and 36-month-old galls because the former contained no dead aphids, while the latter two contained at least one dead aphid that was well mummified. In addition, the gall walls of the former were still soft and the surfaces were tinged with red (Figure 1(b)), while those of the latter two were hard and the surfaces were dark brown with dust (for some exceptional cases, see Section 4.4). Twentynine of the 100 galls were 12 months old (Figure 4(a), white area on the lowest bar). On the other hand, it was not easy to discriminate between 24- and 36-month-old galls. The number of dead aphids varied from one to 37 (mean 4.5, exclusive of those containing no dead aphid). The galls with one or a few dead aphids were likely to be 24 months old, and two that contained more than 20 (24 and 37) dead aphids were likely to be 36 months old.

4.3.4. Galls Collected at the End of March. One hundred coneshaped galls collected on 31 March 2007 were dissected. They were $2.9 \pm 0.7 \mathrm{~mm}$ (range 1.4-5.4) in width and 6.6 $\pm 2.2 \mathrm{~mm}$ (range 2.2-12.0) in height. These galls had not yet resumed growing at that time and the gall walls were hard. The galls would include those that passed two, three, and four wintering seasons, or 21-, 33-, and 45-month-old galls. The number of live aphids in the galls is shown as a histogram in Figure 4(b). The number of dead aphids varied from one to 150 (mean 9.9) and six galls contained more than 50 dead aphids. We could not accurately determine which galls were 21,33 , or 45 months old, but the six galls were likely to be 45 months old and many of those that contained only a few dead aphids to be 21 months old. The number of live aphids ranged from eight to 202 (mean 67.0), and 57 of them contained more than 50 aphids. There was only a weak correlation between gall surface area and the number of live aphids $(r=0.69)$ or the total number of live and dead aphids $(r=0.63)$.

It is worth mentioning here that a fair quantity of wax but little honeydew remained in these galls.

4.4. Some Exceptional Cases. Galls of Nipponaphis monzeni formed in June remain very small until the next spring and grow to cone-shaped galls from April to June in the second year (Section 4.3). However, some galls that had not fully grown in this period were obtained (Table 1). These galls (e.g., two galls collected on 29 October in Table 1) were still very small after one year and contained only two or three live aphids besides one or two dead aphids. During growing



(a)

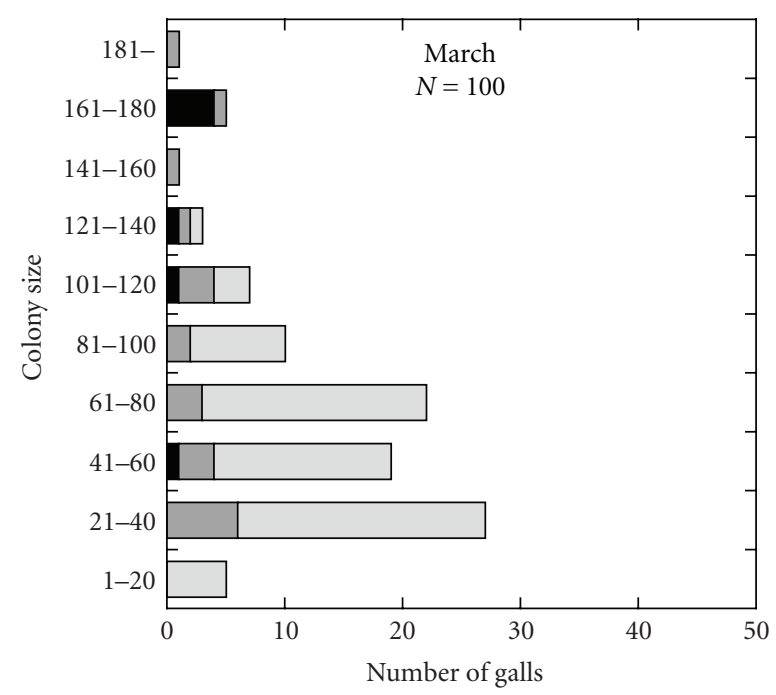

(b)

Figure 4: Colony size (number of live aphids) for 100 cone-shaped galls of Nipponaphis monzeni collected on 2 June 2008 (a) and 31 March 2007 (b). Those galls that contained zero, from one to five, from six to 20, and more than 20 dead aphids are indicated by white, light gray, dark gray, and black areas, respectively, on the bars.

season (e.g., on 2 June 2008), several newly grown coneshaped galls, which contained from one to four dead aphids, were found (Table 1). The dead aphids were well mummified, indicating that they had died long before then. It is very likely that such galls did not grow in the second year and became cone shaped in the third year. These cone-shaped galls would expand to mature in the fourth or fifth year (i.e., after three or four wintering seasons).

4.5. Morphology of Aphids in Young Galls. The adult fundatrix of Nipponaphis monzeni was very small, with short, three-segmented antennae and no cornicles (Figure 5(a)). Mounted specimens were only $0.37-0.47 \mathrm{~mm}$ long (mean 
TABLE 1: Some galls of Nipponaphis monzeni whose growth seems to have been delayed.

\begin{tabular}{lccccc}
\hline Gall $^{\text {a }}$ & Date of collection & Height and width in $\mathrm{mm}$ & No. of live aphids & No. of dead aphids & Estimated age in month \\
\hline $07102-17$ & 29 Oct. 2007 & $? \times 1.2$ & 2 & 2 & 1 \\
$07106-8$ & 29 Oct. 2007 & $2.4 \times 1.9$ & 3 & 16 & 16 \\
$08054-4$ & 2 June 2008 & $7.6 \times 3.4$ & 3 & 2 & 24 \\
$08054-10$ & 2 June 2008 & $1.8 \times 1.4$ & 8 & 2 & 24 \\
$08054-21$ & 2 June 2008 & $4.7 \times 2.0$ & 7 & 6 & 24 \\
$08054-22$ & 2 June 2008 & $4.9 \times 1.9$ & 7 & 1 & 24 \\
$08054-23$ & 2 June 2008 & $3.1 \times 1.6$ & 26 & 4 & 24 \\
$08054-31$ & 2 June 2008 & $4.4 \times 2.1$ & & 24 \\
$08054-41$ & 2 June 2008 & $6.9 \times 2.7$ & & 24 \\
\hline
\end{tabular}

${ }^{\text {a }}$ All galls were collected from Tree S1 in Shinkiba, Tokyo.

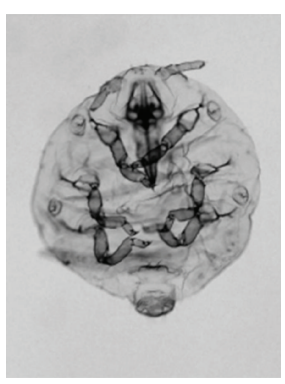

(a)

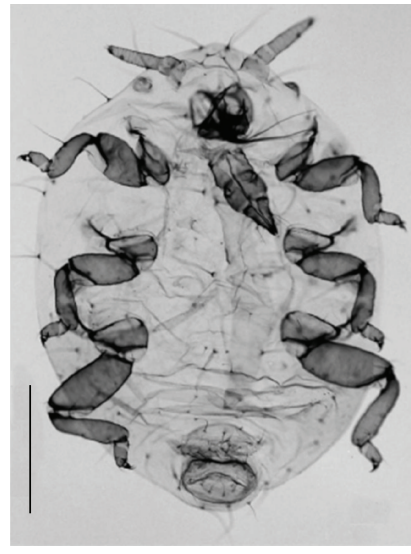

(b)
FIGURE 5: Adults of Nipponaphis monzeni in young galls: fundatrix (a) and thick-legged aptera (second generation) (b). Note the difference in size between them (shown at the same magnification). Scale bar: $0.2 \mathrm{~mm}$.

$0.42, n=10)$. As mentioned before, one or two offspring of the fundatrix develop into apterous adults with greatly thickened hind legs (Figure 5(b)) in May/June of the second year, or in 11- or 12-month-old galls. These thick-legged apterae were much larger than the fundatrix; mounted specimens were $0.60-0.76 \mathrm{~mm}$ long (mean $0.68, n=10$ ), usually (but not always) with a pair of small cornicles. Many thick-legged apterae were also found in those galls that were finally expanding during this season (but they were larger than those produced in cone-shaped galls). By dissecting some expanding galls, we observed that these thick-legged apterae were repeatedly scratching the inner wall of the gall with their thickened hind legs (our unpublished observations recorded on video). Dead thick-legged apterae were found from September onward in cone-shaped 1-year-old galls. From September, when galls had ceased growing, apterous adults with normal (i.e., not thick) hind legs appeared instead of thick-legged apterae. This suggests that the scratching by thick-legged apterae might play some role in the process of gall growing or hardening. Some thick-legged apterae had developed embryos.
4.6. New Records of Secondary Hosts. As the secondary hosts of Nipponaphis monzeni, Quercus glauca [18, 19], Q. myrsinaefolia [23], and Castanopsis sieboldii [19] have been reported. In Shinkiba, colonies of $N$. monzeni were commonly found on Quercus phillyraeoides and Lithocarpus edulis (Figure 1(e)) as well as on Q. glauca during winter. As other researchers reported $[8,18]$, no colonies of $N$. monzeni remained on these secondary hosts during summer.

\section{Discussion}

5.1. Life Cycle. The present study has made it clear that galls of Nipponaphis monzeni initiated in June remain small over a long period. They pass winter at least twice and some of them three times or even four times as small cone-shaped galls (as tiny semispherical galls during the first winter). It takes almost 2.5, 3.5, or 4.5 years for galls of $N$. monzeni to produce alates in December (Figure 2). Although we have focused on galls on a single tree or two (Trees N and S1), the same pattern of delayed gall development was observed on many other trees in Shinkiba and Meguro, Tokyo. From June to December these trees harbored at least three types of galls: tiny semispherical galls, small cone-shaped galls, and expanded large galls. In May/June, new and old cone-shaped galls, and expanding large galls were seen on these trees. In addition, both cone-shaped and expanded galls were at times found at the position of a single axillary bud (Section 4.2.11). These facts strongly suggest that our finding on Tree $\mathrm{N}$ is a rule and not an exception. Sorin [18] and Okuno et al. [26] mentioned that the life cycle of $N$. monzeni is annual. This is clearly not the case. Their mistake is understandable because, when their articles were published, no aphid galls that last for more than one year had been known.

As mentioned before, alates that have crawled out of the gall fly to evergreen oaks and their progeny form open colonies on the twigs. Unlike many other nipponaphidines (e.g., Nipponaphis distyliicola $[4,18]$, Metanipponaphis cuspidatae [8, 30, 31], M. rotunda [32], Quadrartus yoshinomiyai [17]), no aphids remain on the secondary host after alate sexuparae fly back to Distylium racemosum in April/May. Thus, it takes three, four, or five years for N. monzeni to complete its life cycle. In this system, gene flow is assured between yearly cohorts. 
5.2. Origin of the Peculiar Life Cycle. Although the life cycle of Nipponaphis monzeni may seem strange, similar yet shorter life cycles have been reported in two other nipponaphidines. Fundatrices of both Monzenia globuli [27] and Nipponaphis distyliicola [4] form tiny incipient galls on buds of Distylium racemosum in Japan. Galls of $M$. globuli are initiated in May and remain small during the first three or four months and rapidly swell up in September [27]. Galls of Nipponaphis distyliicola are initiated in July and remain small until March or April and grow to the full size in May [4]. Galls of the former species are annual and those of the latter biennial. It is likely that ancestral galls of $N$. monzeni remained small for a shorter period as do present galls of M. globuli or N. distyliicola.

5.3. Why Such a Long Life Cycle? It is rather surprising that a colony of sap-sucking insects can persist for such a long period (for up to 4.5 years) in the completely closed gall. The fundatrix of Nipponaphis monzeni survives for over one year (Figure 3), and other individuals may also survive over several months, judging from the number of dead aphids remaining in the galls (Figure 4). This raises the question how the aphids dispose of their honeydew, which would be dangerous to their life $[33,34]$. The aphids produce wax, but wax-coated globules of honeydew, which are commonly seen in galls of both social and nonsocial aphids [35-37], were not detected from their galls. It remains unknown whether they excrete little honeydew or they remove honeydew in some way.

It is also unknown why some galls of $N$. monzeni take 2.5 years to mature, while others 3.5 or 4.5 years. Although aphids inside the galls perhaps may not enter "diapause" in its physiological sense, this phenomenon is akin to prolonged (or delayed) diapauses, which are known in various insect groups [38] such as weevils [39-41], gall midges [42], and carnid flies [43], and often are interpreted as a bet-hedging adaptation [39]. In the case of N. monzeni, it is also possible that gall inhabitants may avoid competition for nutrition within a yearly cohort that has formed galls on the same or nearby buds. Large galls might draw assimilates more widely from source areas on the plant than small galls, as has been shown for fordine aphids on Pistacia [44-46].

Despite these unanswered questions, there is one clear advantage of their long-lasting galls. During the final expanding phase of the gall (in April/May), nymphs of $N$. monzeni repair their still-soft gall in a self-sacrificing manner when a hole is bored through the wall $[23,24]$. This tactics can work well only if there are many "repairers," or firstinstar nymphs, in the gall. In fact, galls that were expanding in April/May contained approximately 700-2400 live aphids [23]. For aphid species that form annual galls, as each begins with a single fundatrix, it will be difficult to attain such a large colony size at this time. Even in the congener $N$. distyliicola, whose galls are biennial, the colony size during the final expanding phase is approximately from 20 (in late April) to 190 (in late May) [4]. Because of the long pre-expansion period, many galls of $N$. monzeni contain from 50 to more than one hundred live aphids already in March (Figure 4(b)).
This permits the colony to quickly attain a large colony size and hence to prepare many repairers.

\section{Acknowledgments}

The authors thank Shigeshi Usuba and Keigo Uematsu for information about Distylium trees harboring galls of Nipponaphis monzeni. This study was in part supported by a Grant from Chuo University (to U. Kurosu in fiscal years 2008 and 2009).

\section{References}

[1] D. Wool, "Gall-forming aphids," in The Biology of Gall Insects, T. N. Ananthakrishnan, Ed., pp. 11-58, Oxford \& Ibh, New Delhi, India, 1984.

[2] S. Aoki and U. Kurosu, "Biennial galls of the aphid Astegopteryx styraci on a temperate deciduous tree, Styrax obassia," Acta Phytopathologica et Entomologica Hungarica, vol. 25, no. 1-4, pp. 57-65, 1990.

[3] U. Kurosu and S. Aoki, "Long-lasting galls of Ceratoglyphina styracicola, a host-alternating subtropical aphid species," in Aphids in Natural and Managed Ecosystems, J. M. Nieto Nafría and A. F. G. Dixon, Eds., pp. 227-234, Universidad de León (Secretariado de Publicaciones), 1998.

[4] U. Kurosu and S. Aoki, "Galls of the aphid Nipponaphis distyliicola remain closed for more than one year," in Aphids in Natural and Managed Ecosystems, J. M. Nieto Nafría and A. F. G. Dixon, Eds., pp. 235-241, Universidad de León (Secretariado de Publicaciones), 1998.

[5] U. Kurosu and S. Aoki, "Tuberaphis owadai (Homoptera), a new aphid species forming a large gall on Styrax tonkinensis in northern Vietnam," Entomological Science, vol. 6, no. 2, pp. 89-96, 2003.

[6] U. Kurosu, M. Kutsukake, S. Aoki, C.-C. Wang, H.-J. Lee, and T. Fukatsu, "Galls of Cerataphis bambusifoliae (Hemiptera, Aphididae) found on Styrax suberifolius in Taiwan," Zoological Studies, vol. 47, no. 2, pp. 191-199, 2008.

[7] C.-C. Wang, S.-C. Tsaur, U. Kurosu, S. Aoki, and H.-J. Lee, "Social parasitism and behavioral interactions between two gall-forming social aphids," Insectes Sociaux, vol. 55, no. 2, pp. 147-152, 2008.

[8] R. Takahashi, "Aphids causing galls on Distylium racemosum in Japan, with descriptions of two new related species (Aphididae, Homoptera)," Bulletin of the University of Osaka Prefecture, Series B, vol. 13, pp. 1-11, 1962.

[9] D. Noordam, "Hormaphidinae from Java (Homoptera: Aphididae)," The Zoologische Verhandelingen, Leiden, no. 270, pp. $1-525,1991$.

[10] R. L. Blackman and V. F. Eastop, Aphids on the World's Trees: An Identification and Information Guide, CAB International, Wallingford, UK, 1994.

[11] U. Kurosu, I. Nishitani, Y. Itô, and S. Aoki, "Defenders of the aphid Nipponaphis distyliicola (Homoptera) in its completely closed gall," Journal of Ethology, vol. 13, no. 1, pp. 133-136, 1995.

[12] S. Aoki, U. Kurosu, H. Shibao, S. Yamane, and T. Fukatsu, "Defense by a few first-instar nymphs in the closed gall of Dinipponaphis autumna (Homoptera, Aphididae, Hormaphidinae)," Journal of Ethology, vol. 16, no. 2, pp. 9196, 1998. 
[13] T. Fukatsu, H. Shibao, S. Aoki, and M. Sorin, "Attacking behavior of a nipponaphidine aphid, Indonipponaphis fulvicola," Entomological Science, vol. 3, no. 3, pp. 487-490, 2000.

[14] T. Fukatsu, A. Sarjiya, and H. Shibao, "Soldier caste with morphological and reproductive division in the aphid tribe Nipponaphidini," Insectes Sociaux, vol. 52, no. 2, pp. 132-138, 2005.

[15] K. Uematsu, M. Kutsukake, T. Fukatsu, M. Shimada, and H. Shibao, "Altruistic defenders in a Japanese gall-forming aphid, Quadrartus yoshinomiyai (Homoptera: Aphididae: Hormaphidinae)," Sociobiology, vol. 50, no. 3, pp. 711-724, 2007.

[16] M. Sorin, "Three new species and a new subspecies of Aphididae (Homoptera) causing galls on Distylium racemosum from Japan," Bulletin of Kogakkan University, vol. 35, pp. 235-260, 1996.

[17] M. Sorin, "Aphids on the planted trees (4)," Shokubutsu Boeki, vol. 57, no. 10, pp. 480-483, 2003 (Japanese).

[18] M. Sorin, "Life cycles of 2 aphids causing galls on Distylium racemosum," Akitu, vol. 7, pp. 89-92, 1958 (Japanese).

[19] M. Sorin, "Gall of Sinonipponaphis monzeni," in Insect and Mite Galls of Japan in Colors, J. Yukawa and H. Masuda, Eds., p. 212, Zenkoku-Noson-Kyoiku-Kyokai, Tokyo, Japan, 1996.

[20] D. A. Hill, P. W. Lucas, and P. Y. Cheng, "Bite forces used by Japanese macaques (Macaca fuscata yakui) on Yakushima Island, Japan to open aphid-induced galls on Distylium racemosum (Hamamelidaceae)," Journal of Zoology, vol. 237, no. 1, pp. 57-63, 1995.

[21] M. Moritsu, Aphids of Japan in Colors, Zenkoku-NosonKyoiku-Kyokai, Tokyo, Japan, 1982.

[22] S. Kitamura and G. Murata, Colored Illustrations of Woody Plants of Japan, vol. 2, Hoikusha, Osaka, Japan, 1979.

[23] U. Kurosu, S. Aoki, and T. Fukatsu, "Self-sacrificing gall repair by aphid nymphs," Proceedings of the Royal Society B, vol. 270, pp. S12-S14, 2003.

[24] M. Kutsukake, H. Shibao, K. Uematsu, and T. Fukatsu, "Scab formation and wound healing of plant tissue by soldier aphid," Proceedings of the Royal Society B, vol. 276, no. 1662, pp. 15551563, 2009.

[25] M. Sorin, “Aphids on trees (5)," Forest Pests, vol. 25, no. 4, pp. 46-51, 1976 (Japanese).

[26] T. Okuno, Y. Tanaka, and Y. Kimura, Diseases and Pests of Cultivated Trees and Shrubs in Colour, Hoikusha, Osaka, Japan, 1977.

[27] I. Nishitani and Y. Itô, "Delayed development of the galls and life cycle of the monophagous aphid, Monzenia globuli (Monzen) (Homoptera, Aphididae)," Japanese Journal of Entomology, vol. 59, no. 3, pp. 577-580, 1991.

[28] S. Aoki, U. Kurosu, and W. Sirikajornjaru, "A new soldierproducing aphid species, Pseudoregma baenzigeri, sp. nov., from northern Thailand," Journal of Insect Science, vol. 7, article 38, pp. 1-10, 2007.

[29] Y. Tosaka and T. Nishida, "Gall surface area is a simple and accurate measure of fitness in Nipponaphidini galling aphids (Homoptera: Aphididae)," Applied Entomology and Zoology, vol. 42, no. 2, pp. 217-221, 2007.

[30] M. Sorin, "Life cycles of two aphids causing galls on Distylium racemosum (Aphididae, Homoptera)," Seitai Konchu, vol. 8, no. 3, pp. 105-110, 1960 (Japanese).

[31] M. Sorin, “Aphids on trees (6)," Forest Pests, vol. 26, no. 1, pp. 4-13, 1977 (Japanese).

[32] R. Takahashi, "Some aphids related to Nipponaphis Pergande in Japan (Homoptera)," Bulletin of the University of Osaka Prefecture, Series B, vol. 9, pp. 1-8, 1959.
[33] M. Inbar and J. C. Schultz, "Once again, insects worked it out first," Nature, vol. 414, no. 6860, pp. 147-148, 2001.

[34] N. Pike, D. Richard, W. Foster, and L. Mahadevan, "How aphids lose their marbles," Proceedings of the Royal Society B, vol. 269, no. 1497, pp. 1211-1215, 2002.

[35] L. Broadbent, "Aphid excretion," Proceedings of the Royal Entomological Society of London, Series A, vol. 26, parts 7-9, pp. 97-103, 1951.

[36] S. Aoki and U. Kurosu, "Soldiers of Astegopteryx styraci (Homoptera, Aphidoidea) clean their gall," Japanese Journal of Entomology, vol. 57, no. 2, pp. 407-416, 1989.

[37] T. G. Benton and W. A. Foster, "Altruistic housekeeping in a social aphid," Proceedings of the Royal Society B, vol. 247, no. 1320, pp. 199-202, 1992.

[38] M. R. Defaria, "Longest diapause among insects," in University of Florida Book of Insect Records, chapter 3, 2001.

[39] F. Menu, J.-P. Roebuck, and M. Viala, "Bet-hedging diapause strategies in stochastic environments," The American Naturalist, vol. 155, no. 6, pp. 724-734, 2000.

[40] K. Maeto and K. Ozaki, "Prolonged diapause of specialist seed-feeders makes predator satiation unstable in masting of Quercus crispula," Oecologia, vol. 137, no. 3, pp. 392-398, 2003.

[41] Y. Matsuo, "Cost of prolonged diapause and its relationship to body size in a seed predator," Functional Ecology, vol. 20, no. 2, pp. 300-306, 2006.

[42] T. Sunose, "Studies on extended diapause in Hasegawaia sasacola Monzen (Diptera, Cecidomyiidae) and its parasites," Kontyû, vol. 46, no. 3, pp. 400-415, 1978.

[43] F. Valera, A. Casas-Criville, and M. A. Calero-Torralbo, "Prolonged diapause in the ectoparasite Carnus hemapterus (Diptera: Cyclorrhapha, Acalyptratae): how frequent is it in parasites?” Parasitology, vol. 133, no. 2, pp. 179-186, 2006.

[44] M. Burstein, D. Wool, and A. Eshel, "Sink strength and clone size of sympatric, gall-forming aphids," European Journal of Entomology, vol. 91, no. 1, pp. 57-61, 1994.

[45] M. Inbar, A. Eshel, and D. Wool, "Interspecific competition among phloem-feeding insects mediated by induced hostplant sinks," Ecology, vol. 76, no. 5, pp. 1506-1515, 1995.

[46] D. Wool, "Gall-inducing aphids: biology, ecology, and evolution," in Biology, Ecology, and Evolution of Gall-Inducing Arthropods, A. Raman, C. W. Schaefer, and T. M. Withers, Eds., vol. 1, pp. 73-132, Science, Enfield, NH, USA, 2005. 

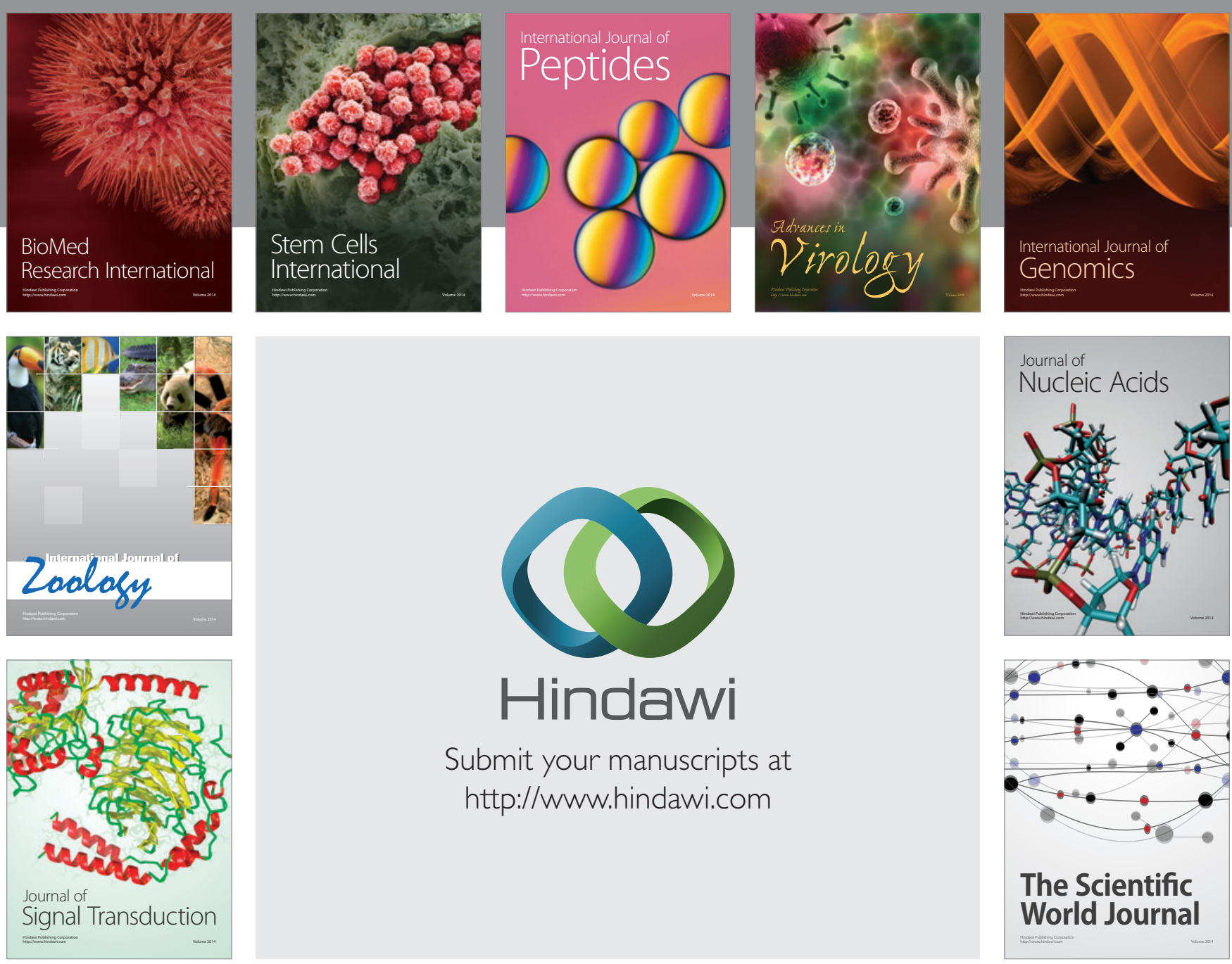

Submit your manuscripts at

http://www.hindawi.com
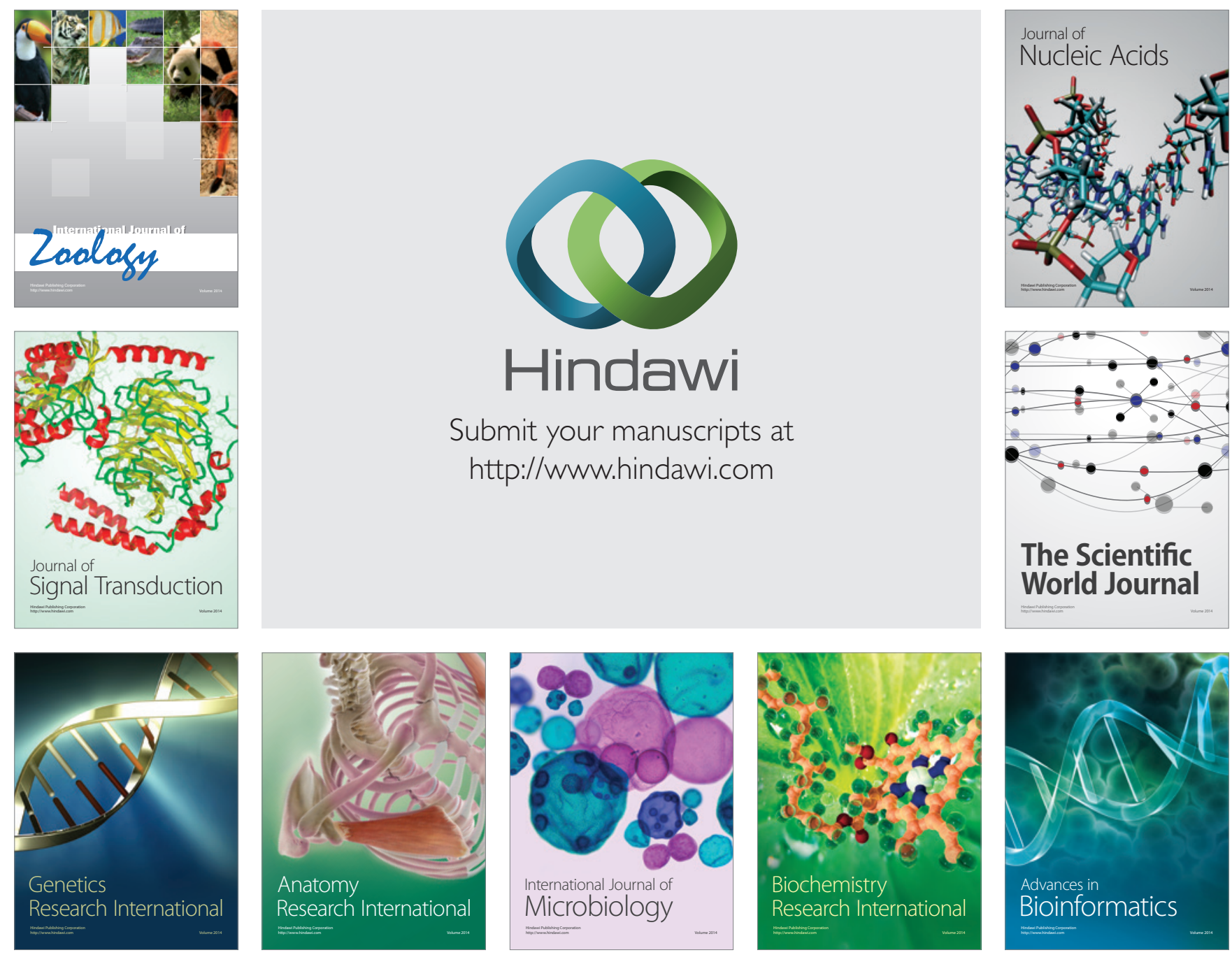

The Scientific World Journal
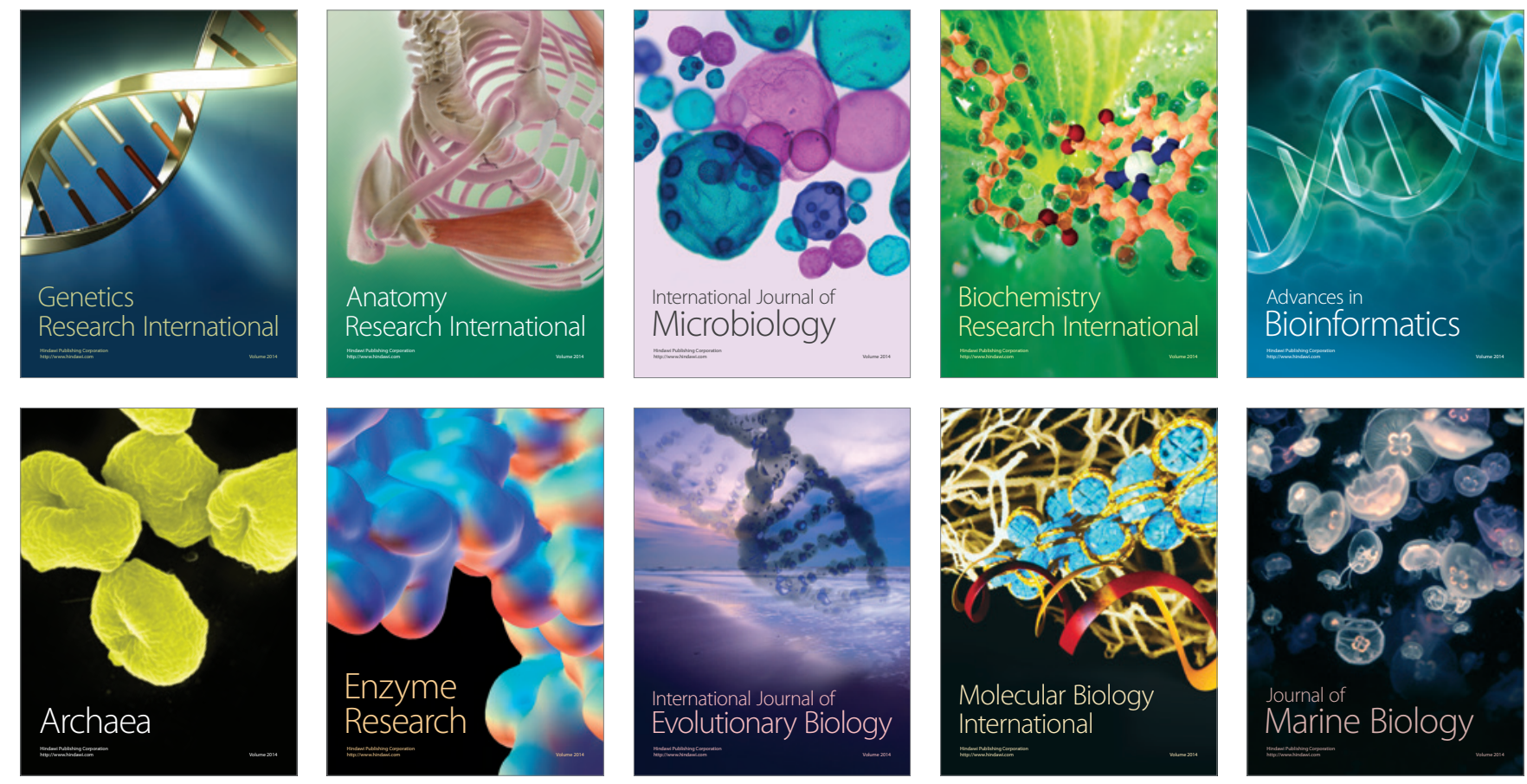